\title{
'Britishness', Colonial Governance and Education: St Helenian Children in Colonial Natal in the 1870s
}

\author{
Rebecca Swartz ${ }^{\mathrm{a}, *}$ and Johan Wassermann ${ }^{\mathrm{b}}$ \\ ${ }^{a}$ Historical Studies, University of Cape Town, Rondebosch, South Africa; \\ $\mathrm{b}_{\text {School of Education, University of Pretoria, Hatfield, South Africa }}$ \\ ${ }^{\star}$ Correspondence to: rebecca.swartz@uct.ac.za
}

\begin{abstract}
This article considers understandings of 'Britishness' in the Natal colony in the 1870s. Focusing on St Helenian children's expulsion from 'government' schools that were ostensibly open to all racial groups, the article shows how competing definitions of race and 'Britishness' shaped the responses of colonial officials, settlers and the St Helenian community to the expulsion. The white settler population in Natal was concerned about St Helenian economic migrants' inclusion in white, English society. In particular, the ambiguous racial status of St Helenians was seen as potentially harmful to white children. The focus on a group of recent incomers to the colony uncovers a process of racialisation unfolding in the context of migrations within the British Empire. The case highlights how movement and migration within the empire could bring these definitions of race and Britishness into conversation and conflict with each other.
\end{abstract}

\section{Keywords}

Natal; St Helena; education; childhood; Britishness

This article focuses on one case that took place in colonial Natal. The case attracted the attention of colonial officials and the Aborigines Protection Society, a humanitarian organisation based in Britain. In 1875, St Helenian children were removed from the government school in Durban. There was one example that the Aborigines Protection Society brought to the notice of their international readership: the Durban government primary school in Queen Street had differentiated between two St Helenian girls, the daughters of a Mrs Sherrard. According to the Society, the elder girl was 'slightly bronzed', or 'olive', and the younger 'quite white. ${ }^{1}$ The younger girl was re-admitted to the school the day after the expulsion, while the elder, darker girl, was denied access to the institution.

This article considers the context in which this case took place, arguing that competing ideas about race and Britishness framed the discussion of children's access to education. The case deals with the experience of people who were very recent immigrants to Natal and thus it demonstrates a process of racialisation 
and othering at the moment of its unfolding. Movement and migrations within the British Empire could result in competing understandings of what it meant to be British. In this article we see the migrant population being, and refusing to be, constructed as 'undesirable', according to both race and morality. ${ }^{2}$

Scholarship on race and childhood has highlighted the 'fragility' of whiteness as a racial category, particularly for children. ${ }^{3}$ The first aim of this article is to add to a growing historiography on race and childhood in the British Empire and beyond. ${ }^{4}$ The ambiguous racial identity of the St Helenian community in Natal brought anxieties about the stability of racial categories, and in particular about how racial mixing would affect white children, to the surface. Elizabeth Buettner's work on Anglo-Indian families shows that white parents in British India were more concerned about their white children having contact with 'Anglo-Indians' than their 'mingling with "natives"'. ${ }^{5}$ Similarly, Ann Stoler has drawn the attention of scholars of empire to the instability of racial categories in colonial settings. In the Dutch Indies "[n]ative and mixed-blood "character" was viewed as fixed in a way that European "character" was not', which made white children particularly vulnerable to the influence of an immoral 'other'. The presence of 'non-white', or ambiguously raced, children in schools could challenge the exclusive socialisation into whiteness that children were receiving in these spaces. In a place like colonial Natal, where political power was related to skin colour and claims to Englishness, the fears that white children would be mis-educated and turn out non-white was very present.

The concept of childhood has generally been overlooked in South African historiography. Edna Bradlow's work on the Cape mapped some of the differences between middle-class and poorer childhoods, but did not pay much attention to the racial contexts of childhood and education. ${ }^{7}$ Sarah Duff's more recent contribution, also focused on the Cape, highlights the importance of race for histories of childhood in South Africa. She argues that poor white children were seen as a 'threat to the social, moral, and even economic order' in the late nineteenth century, and that attempts to educate and improve the conditions of poor white children were intimately tied to 'moulding and forming white, young men into the kinds of citizens educationalists and colonial commentators believed would be beneficial to Cape society. ${ }^{8}$ In the African context more broadly, historians of education have been criticised for being preoccupied with recording the effects of 'Western' education and 'cultural whiteness' on African people, and for overlooking that 'the displacement of European settlers into colonial time and space might have left an imprint on colonizing societies themselves and on White settlers in particular. ${ }^{9}$ Robert Morrell's work addresses this oversight by examining the creation of settler masculinities in colonial Natal. Morrell provides an important way into thinking about the construction of racial difference and whiteness in schools. ${ }^{10}$ The article builds on Morrell's approach by examining the relationship between childhood and white identity when these were directly challenged by the presence of a racial 'other'. 
The second aim of this article is to demonstrate how competing definitions of Britishness were articulated in this colonial context. The arrival of the St Helenians in Natal brought into conflict two distinct ideas of what it meant to be British. This conflict played itself out in schools. One important marker of white identity in Natal was a claim to Britishness, and with it respectability. By the 1870s, there were about 25,000 white settlers in the Colony, making up 6 per cent of the population. ${ }^{11}$ As the number of settlers in the colony increased, so too did the perceived importance of racial segregation. Previously made up of a number of Zulu chiefdoms, the colony was formally annexed by the British in 1842, after a brief period as the Boer Republic of Natalia. While mixed-race relationships had been a more common feature of life before annexation, 'the post-frontier settler displayed a racial and cultural chauvinism that had never been prevalent among the early Port traders'. ${ }^{12}$ The British claimed that there would be no legal restrictions on the inhabitants of the colony based on their race, religion or place of origin. However, it became increasingly apparent that Natal was a colony driven by the needs of a growing white settler class, who exerted a strong influence on the local colonial government. ${ }^{13}$ 'Whiteness' became a 'defining, not a defined category', and those who were not white, especially Africans, were cast as backward and inferior, justifying possession, oppression and colonisation of land and people. ${ }^{14}$ Increasingly, settlers understood Britishness and white identity as synonymous.

However, as David Killingray has shown, 'Britishness' meant 'different things to different people all over the world, and was shaped by origin, place of residence, social class and accent, culture, as well as law. ${ }^{15}$ Different groups, therefore, 'performed Britishness in diverse ways. ${ }^{16}$ For St Helenians arriving in Natal, the liberal promise of equality in the British Empire shaped their claims for access to government-funded institutions. The local colonial, and imperial, government needed to mediate between these conflicting definitions of 'Britishness'. This article highlights the importance of context in understanding how the idea of Britishness was drawn upon to justify access to particular institutions.

St Helena became a crown colony in 1834 . While the island was a logistical and administrative hub for the East India Company, St Helenians were employed in administration, farming and the maritime sector. The significance of the island began to wane for a number of reasons, including the opening of the Suez Canal, lack of East India Company financial and logistical support and the financial burden of the arrival of many rescued and freed slaves from America and West Africa. Gosse referred to the island as the 'poor forgotten orphan of the British Empire', referring both to a significant lack of interest in the colony from the Colonial Office and a dearth of historical enquiry on the island since. ${ }^{17}$ While there has been some research on race and St Helena's colonial past, the relationship between St Helena and South Africa, and Natal in particular, has largely been overlooked. ${ }^{18}$ 
Successive colonial presences in St Helena left behind a population of diverse ancestry with links to Portuguese, British and Dutch sailors, Malay, African, Goan, Madagascan and Sumatran slaves, Chinese labourers, French servants, American whalers and English families. ${ }^{19}$ The absence of an indigenous population did not hold nineteenth-century accounts back from 'the construction of a St Helenian "native", a discourse which is indeed comparable to colonial discourses about an indigenous "Other"' ${ }^{20}$ Apart from attempts to classify the St Helenian 'native' in terms of skin colour-'a very light brown or copper, sometimes deepening into nearly black' - the character of the St Helenian came to be associated with 'indolence' and 'ignorance', echoing the characterisation of indigenous people in other British colonies. ${ }^{21}$ These sorts of characterisations of the 'native' would have resonated with the English settler community in the Natal colony. As St Helenians began to migrate in increasing numbers to the South African colonies, these conceptions of their race followed them across the Atlantic Ocean. In the context of an increasingly racialised British Empire, the interracial mixing that characterised the island's population became troublesome, and Natal settlers attempted to maintain the racial 'purity' of their community. ${ }^{22}$

It is worth pointing out that St Helenians migrating to the South African colonies were sensitised to the fact that they were to meet a racial 'other'. For example, the St Helenian Guardian referred to the 'half-savage' people of South Africa with whom the St Helenians might be faced, and made it clear that the St Helenians were not themselves part of this group. ${ }^{23}$ This kind of racial thinking also played into the St Helenians' reaction to their exclusion from white society.

A wave of St Helenian people, in search of economic opportunities, migrated to the South African colonies in the 1870s. Large numbers of St Helenians were unemployed, and were seeking alternative prospects within the British Empire. ${ }^{24}$ Their presence became troublesome for an English settler colony increasingly turning to race as a marker of social status and class. ${ }^{25}$ Between 1,000 and 2,000 St Helenians settled in the Cape and Natal, out of the island's total population of some 5,000 to $6,000 .{ }^{26}$ Between 1873 and 1874, 800 St Helenians settled in Natal to take up work as domestic servants, for the Pietermaritzburg Corporation, as manual labourers on the sugar cane plantations or for Natal Government Railways. Many of these St Helenian contract labourers were brought to Natal to make up for a labour shortage in the colony when the import of indentured labourers from India was halted for a time from $1866 .{ }^{27}$ In the small colonial cities of Durban and Pietermaritzburg the St Helenians were from the outset a very small, but visible, group in a conservative Victorian colony that was conscious of both class and colour.

As the case unfolds below, we see the how the connections between Natal and St Helena raised concern about the racial identities of children in these spaces. We are also reminded of the ways in which the conception of 
'British' identity was always the subject of much debate. As we move through the sequence of events in the case, we see competing ideas about race, Britishness and the protection of empire emerging from communities in flux. The article begins by discussing the educational context in which the case took place and providing a detailed account of the removal of St Helenian children from government schools in Natal. It then demonstrates the implications of this case for understandings of Britishness, race and childhood in colonial Natal and beyond.

\section{Education in Colonial Natal: Britishness and St Helenian Migration}

Government involvement in the provision of education in Natal had a fairly slow start. The first 'public', or government, primary school was opened in Pietermaritzburg in 1849, and in the following year another government school was opened in Durban. ${ }^{28}$ High schools were opened in Pietermaritzburg in 1863 and in Durban in 1866. The other available schools at the time were stateaided and were run by individuals or missionary societies. All government and government-aided schools were compelled to admit black children if they 'conformed to 'European habits and customs'. ${ }^{29}$ The Verulam School, in the 1850s, for example, had 29 white and 13 black pupils on the roll. However, this was the exception rather than the rule. Although black children could not actively be excluded from schools the vast majority were taught by missionaries in the government-aided schools. ${ }^{30}$ Indian children were taught in schools provided for by the Indian Immigrant School Board. ${ }^{31}$ The outcome of this was that the four government schools and the government-aided schools were, in practice, generally racially exclusive. The schools were often segregated in terms of gender as well, as many parents of white girls felt that the government education provided in the colony was not suitable for their daughters. ${ }^{32}$ The schools for white pupils were rudimentary in terms of personnel, premises and pedagogy, but they were still important sites of colonial privilege that served to socialise white children, for the brief periods that they did attend school, in terms of gender identity and the meaning of their race as a manifestation of British identity. ${ }^{33}$

St Helenian children began to be admitted to the Durban government primary school in Queen Street, as well as other government-aided schools, in October 1873. Their access to the government school was initially facilitated by the Durban Benevolent Society. ${ }^{34}$ At first, the presence of this group of immigrant children raised no objections, although their presence was noted and some were mentioned in local newspapers for their academic ability and 'good behaviour'. ${ }^{35}$ However, this period was short lived, and in August 1874 the acting headmaster of the government primary school, W. J. Hepworth, wrote to the government-appointed superintendent of education, T. Warwick Brooks, in some embarrassment, pointing out that: 
The other day two St Helena children were sent to me, whom I objected to receive until I had communicated with you. I already have five St Helena children in the school, but as there is no objectionable difference in them from the other children either in point of colour or behaviour, I had no reason to hesitate to receive them. But the two I have refused were of the colour bordering on the black and this made me reflect whether the European parents might not raise serious objections to their children mixing with the St Helena ones. You are doubtless aware that there is a strong repugnance down here against the St Helena people, as a body on account of their immorality. ${ }^{36}$

Hepworth was anxious about protecting the reputation of the school, and preventing any scandal which might arise from the admission of these children. Brooks' response was emphatic:

I do not think that their colour should exclude these children provided (as is probably the case) that they have been brought-up with the ideas and under the restraints of ordinary European civilization. You will therefore admit these children and if any complaint is made you will be kind enough to ask the complainants to address themselves directly to me. ${ }^{37}$

The children were admitted, and there were no immediate complaints from white parents. The dilapidated Queen Street School continued with its business under the acting headmaster and his two assistant teachers. ${ }^{38}$ During this time the number of St Helenian children in the school grew, and by the first quarter of 1875 they amounted to around 25 pupils. ${ }^{39}$

However, this was not the last that would be heard about the St Helenian children. Towards the end of the first quarter of 1875, the new headmaster, James Crowe, recently arrived from England to become the headmaster of the newly built government school, complained to Brooks about the St Helenian children. Like his predecessor, Crowe pointed out that ' $[t]$ he feeling here is very much against them. I am of the opinion there would be less opposition from parents if Kafirs or coolies [sic] attended the school. ${ }^{40}$ Crowe claimed that white parents were withdrawing their daughters from the school, and refusing to enrol new pupils. While he claimed that he had no objection to the St Helenian children himself, Crowe felt he needed to look after the interests of his school and take action. As long as the St Helenian children were present, his school would, he claimed, play second fiddle to the government-aided St Cyprians School which he claimed did not accept St Helenian children. Crowe asked for Brooks' help in the matter, saying, 'there will be no doubt of our success in Queen St. but we must start evenly in the race. ${ }^{41}$

This seems to have been the catalyst for Brooks reconsidering his earlier stance on the admission of the St Helenian children into the Durban school. Most worrying for Brooks, as his subsequent reports reveal, was the claim that the parents of white girls were withdrawing their children from the government school. ${ }^{42}$ Brooks saw the new school, 'with its expensive staff, and handsome accommodation for 120 boys and girls and 40 infants', as central to the educational future of the colony. Not only did he need to safeguard the white 
girls from racial 'others', but the school was also to serve as a training school for 'female pupil teachers'. The success of the school, both financially and in terms of its reputation, was reliant on the presence of white girls there.

The correspondence does not reveal how the decision was made to expel the St Helenian children from the government school, although Brooks, as the superintendent of education, must have driven it, in consultation with members of the Legislative Council and the governor, Sir Garnet Wolseley. ${ }^{43}$ In April 1875, all of the St Helenian and other coloured children enrolled in the Queen Street School were called into a lobby by Crowe, and were told that instructions had been issued that they could no longer be taught there. Some expelled St Helenian children recalled that, when they were turned away from the school, they were told that it was on the governor's orders. ${ }^{44}$ Among those expelled were Mrs Sherrard's two daughters. Superintendent Brooks explained that this decision had been taken in 'a provisional manner by way of experimenting' and that he awaited further instructions from the government. ${ }^{45}$

\section{Imperial Citizens?}

In the weeks and months that followed, the Natal St Helenian community made themselves more visible, not only to local colonial officials and newspapers, but also to the Aborigines Protection Society and the Colonial Office. In their correspondence, claims to British identity were used to justify their children's access to the public schools. The cultural ties between Britain, St Helena and Natal, and the values which this group associated with the British imperial project, were drawn upon to legitimise St Helenian claims to racial equality. The St Helenian children's fathers attempted to claim Britishness as a way of justifying their presence as imperial citizens, and their access to public institutions.

Following the expulsions, a deputation of St Helenian fathers sent letters to the lieutenant-governor of Natal and the colonial secretary respectively. In April 1875, in a letter to the lieutenant-governor, the St Helenians described themselves as '[l]oyal subjects of Her Most Gracious Majesty the Queen formerly enjoying the full privileges of British subjects'. They wrote that their children had been removed from the government school 'solely on account of their colour'. They drew the governor's attention to the case of the Sherrard children, the one who was 'fairer than the other' who was kept in the school, while the other was removed from the school, along with some other children whose parents were from the Cape of Good Hope. ${ }^{46}$

Later that year, a deputation of three St Helena men wrote to the colonial secretary, asking "why, such a step should be taken on the part of the government to form "Caste" although no misconduct of the children that they were expelled $[s i c] \cdot{ }^{47}$ In this letter, the parents pointed to what Brooks had outlined to the colonial secretary: that the children were being treated as a separate group, 
although they had not behaved badly or given any cause for their expulsion from the school. The parents clearly understood the expulsion of their children to be on racial grounds, and needed to work to prove their respectability and, with it, their legitimate presence as part of white Natal society. They went on to say:

We are greatly surprised by the ignorance displayed by the Superintendent of Education in the matter of the manners and customs of the St Helena people, having no nationality of their own, their institutions being wholly English.

We can speak from experience that in the cities of Boston, and New Bedford, United States of America, the children of respectable St Helena parents have access to any of the high schools, but not in such an insignificant place as Durban.

For the parents, being citizens in the British Empire meant that they should have been treated as part of the white, English settler society. Making the comparison between 'insignificant' Durban and two cities in the United States gives a sense of the parents' understanding of their position within the empire. The American cities, and New England in particular, had in the course of the nineteenth century seen large numbers of immigrants from various parts of the world, who, the St Helenian fathers believed, were being treated on a more equal footing than they were in colonial South Africa. ${ }^{48}$

There was another element to the complaints against the St Helenians, to which the group of fathers responded. The fathers said that they were facing wide-spread discrimination, as ' $\mathrm{t}$ ] he dislike of the poor whites, are not confined to the children alone, but to the whole of the St Helenians' $[$ sic $] .{ }^{49}$ They claimed that this was because St Helena men were successfully finding work in the 'principle stores and places in Durban'. The challenge posed by the racially ambiguous St Helenian people's introduction to Natal also had a class dimension. If whiteness in Natal was associated with the English language, middle-class values and respectability, the presence of a group of poor people who claimed to be white and British could be deeply challenging. This is similar to what Duff has shown in the Cape colony, where debates about the education of poor whites showed that "[b]eing "civilised" was not only associated with whiteness, but also with being bourgeois'. ${ }^{50}$ In the case of the St Helenian children, part of the difficulty with their classification was about their class status, and the fact that many of them came from poor backgrounds meant that there was anxiety about whether class, as well as race, could be learnt and passed between children in this context.

The St Helenian fathers, clearly aware of the negative characterisations of their community, distanced themselves from the 'few lost characters' who had arrived in the Natal colony from St Helena, stating this 'deplorable class' should not be 'considered typical of the whole'. They concluded by saying that they hoped that the government would remedy the situation, and stop supplying education on the grounds of what they referred to as 'caste', as they would, they wrote, 'use most strenuous efforts to obtain the rights and privileges 
of Free born English speaking British subjects'. ${ }^{51}$ When their letter had been acknowledged but not responded to by Wolseley, Crowley and Green, two representatives of the group, wrote that, since the lieutenant-governor had left

from the Colony without the least recognition of what is most near and dear to us, namely the education of our children, and finding that it is your intention to govern us by Class legislation, we are reluctantly compelled to forward our grievance to England. ${ }^{52}$

This they did, and the case percolated further through the networks of colonial government and humanitarian organisations. Meanwhile, a full enquiry followed and Sir Garnet Wolseley concluded that there was no reason that European and St Helenian children should not be admitted on the same footing to government schools. A government notice was accordingly released, stating 'all government schools are open to all classes of Her Majesty's subjects' ${ }^{53}$

After the parents forwarded their grievance to the Colonial Office, the case was taken up by Henry Richard of the Aborigines Protection Society, and correspondence surrounding the case was printed in the society's mouthpiece, The Colonial Intelligencer. As far as the Aborigines Protection Society was concerned, 26 St Helenian children had been expelled from the school in Natal 'solely on account of the children's colour' ${ }^{4}$ The fact that the case was taken up by the Aborigines Protection Society, a group devoted to advocating the rights of 'native races' around the world, is significant, as it indicates that the society understood that the St Helenians were racially different from their European Natal contemporaries and that the complaints made against them attending the same schools as European children were based primarily on race. ${ }^{55}$ In September 1875, Carnarvon relayed this letter from the society to Sir Henry Bulwer, the newly appointed lieutenant-governor. Carnarvon asked for a full report on Frank Chesson's, the society secretary's, accusation that the exclusion of the St Helena children had been 'solely on the ground of the children's colour'. More specifically, he pointed out that:

Our attention is also drawn to the fact that among the children there were two sisters one of whom in consideration of the fairness of her complexion was allowed to remain in the school while the other who had the misfortune to possess a dark skin was sent back to her family. ${ }^{56}$

As the investigation of the case escalated from the level of a school headmaster and the superintendent of education, to the colonial secretary, lieutenant-governor, and finally to the secretary of state for the colonies, we see many conflicting interpretations of the events at hand. The fact that the case was taken up at this high level of colonial governance is indicative of what was at stake in the decisions surrounding it: inclusion of the St Helenian children could challenge white settler supremacy in the colony, but to exclude them to please the 
settler elite would fundamentally challenge the idea of 'Britishness' as a protective and inclusive concept. In a small colony like Natal, with a newly arrived lieutenant-governor, the potential for scandal would have driven the colonial officials to resolve the case as quickly as possible, particularly in light of the fact that the case had risen to the level of the Colonial Office.

Bulwer, eager to protect his reputation with the Colonial Office, decided to launch his own investigation. Counter to what the Aborigines Protection Society claimed, Frederick Napier Broome, then colonial secretary, argued that Brooks had stated that the children were expelled not because of their colour, but because of the feelings of European parents, who complained that the St Helenian children 'were so depraved and vicious that they, the European parents, would not allow their children to associate with them' ${ }^{57}$ However, Crowe's interview about the exclusion of the St Helenian children told a different story. While initially he claimed that the complaints against the St Helenian children were on account of their 'moral' deviations, he later argued that the objections of the parents were on account of colour and that the school had been 'refusing any [child] with a trace of coloured blood'. ${ }^{58}$

However, this did not resolve the matter for Bulwer, who was still unsure of the details of the case. Brooks was asked to reinvestigate the expulsion, particularly of the Sherrard girls, by interviewing the teachers involved and studying the books of the school. ${ }^{59}$ Brooks also spoke to the Sherrard family and the St Helenians who had signed the petition. In his report to Bulwer, Brooks was dismissive of the testimony of the St Helenians, saying that it proved difficult to

obtain evidence of facts (and the order of occurrence) which happened now more than ten months ago mostly from excited women and children who have heard the facts talked about, they can hardly separate what they heard from what they saw. ${ }^{60}$

In spite of Brooks' reinvestigation, Bulwer remained concerned that the 'facts' of the case had not been adequately addressed. In particular, he had not seen enough evidence that white girls had, in fact, been removed from the Durban school. In the midst of this investigation, Bulwer was trying to negotiate the relationship with Brooks, whom he clearly saw as incompetent. In the margins of Brooks' report, Bulwer commented: 'I cannot help observing to the Superintendent that the untruthful way in which some of my questions were answered has been extremely inconvenient in my endeavour to come to a just conclusion on the merit of the matter. ${ }^{61}$ Bulwer was anxious to prove that the events described by the Aborigines Protection Society had not taken place, and Brooks later concluded, whether to please Bulwer, or because of a new interpretation following the investigation, that ' $\mathrm{I}$ was under a mistake as to the withdrawal of white girls'. ${ }^{62}$ This case was as much about the 'facts' according to those involved, as it was about the relationship between colonial officials, and contestations of the meanings of race and difference in the colony. In an 
empire that claimed racial equality, it was important for the case to be dealt with swiftly, without bringing further international attention to the matter.

Bulwer continued his investigations, this time asking the Durban resident magistrate to interview the mother of the children who had been expelled. ${ }^{63}$ Mrs Sherrard, either intimidated by the visitations of the officials to her home or weary of their presence, said that she struggled to recollect what had transpired when her daughters were expelled. What she did recount with more confidence was a conversation with headmaster Crowe, which resulted in her children being allowed back into the school. ${ }^{64}$ This version of events would have been more pleasing to Bulwer, who was invested in proving that the expulsions had not been racially motivated. In the weeks that followed, Bulwer went to Durban to investigate the expulsion himself, although his enquiries clearly added little to the information which had already been collected about the case. ${ }^{65}$ In a final attempt to clarify matters, Brooks was asked to write an 'exact' report on the case. ${ }^{66}$ Again, the 'facts' of the matter were hard to come by, and Bulwer must have concluded that this was as far as the investigation should go. ${ }^{67}$

Early in 1876, Bulwer forwarded a report, along with a range of supporting documents, to the secretary of state for the colonies as a reply to the claims made by the St Helenian memorialists and the Aborigines Protection Society regarding the Sherrard children and the wider expulsions of the St Helenian children from the government school in Durban. ${ }^{68}$ Bulwer presented the case as a misunderstanding, claiming that the one of the Sherrard girls had been mistakenly expelled with the rest of the St Helenian children. The mistake had, according to Bulwer, been immediately rectified. Bulwer therefore argued that the St Helenian petitioners and the Aborigines Protection Society gave an 'erroneous' interpretation of what they deemed to be the racial distinction made between the two sisters. In Bulwer's interpretation, the case had never been about 'colour' but, rather, the 'gross immorality' of the St Helenians. ${ }^{69}$

This interpretation did little to convince the Colonial Office. They argued that, 'though the immorality of the St Helena immigrants is stated to be the principal cause of the prejudice against them, it seems that colour had a good deal to do with it'. However, since the schools had been declared open, the Colonial Office adopted a stance that supported Bulwer and his report. He was commended for going to great care in the investigation. The event was passed off as an 'accident which was afterwards rectified'. 70

\section{Race, Class and the Colonial Order}

What do we make of a case like this one, in which a minority group claimed their rights based on their imperial identities as British subjects? There are multiple ways in which the case sheds light not just on the individual actors involved, but also on the relationship between colony and metropole and broader understandings of what it meant to live in the British Empire. 
The case brought fears about racial purity to the surface, whether defined in terms of race or class. These fears were directed at white children, and girls in particular. One of the most striking features of the case under study is the lack of clarity about the race of the St Helenian children. The St Helenian children could not be easily racially classified, which was particularly straining of a social order increasingly based on race. It is no coincidence that the space in which complaints about this ambiguity were raised was a school environment. In Natal, the racial ambiguity of the St Helenian children was seen as particularly harmful to white children whose own racial identities were seen as fragile and were being moulded in relation to changing social circumstances in the colony.

In the last decades of the nineteenth century, children began to be seen as the 'future of the nation and of the race'. ${ }^{71}$ Robert Morrell's work on elite boys' secondary schools in colonial Natal showed that schools formed an integral part of social engineering' in that colonial context. Access to education was related to power within colonial society. 'Those excluded or denied partial access belonged to marginal social groups, the working class, the colonised, or, in general terms, those outside the ruling bloc. ${ }^{772}$ Schools served as 'signifiers of settler values', 'bastions of civilisation against the imagined threat of octopus-like black barbarity'. ${ }^{73}$ Similarly, as Buettner argues in the Indian context, education was central to the 'process of racial definition, with schools acting as crucial spaces in which interdependent racial and class identities were brought to the surface and often reconstituted'. ${ }^{74}$ The school was understood as a place where white, settler values could be transmitted, and the admission of non-whites to these spaces was potentially threatening. Racial ambiguity was seen as harmful to white children. The fact that St Helenians ranged from 'a colour bordering upon the black' to looking like 'Saxon [maids]' meant that the boundaries between the racial groups needed to be protected even more fiercely, as these children were the embodiment of perceived racial mixing, and thus were symbolic of a disruption of the social order. Crowe's argument that 'there would be less opposition from parents if Kafirs or coolies [sic] attended the school' illustrates this perception. ${ }^{75}$

Woven throughout this case are particular concerns about the effects of interracial mixing on white girls. European parents were particularly worried about their white daughters mixing with St Helenian girls. Sons of white colonists commonly played with African boys of a similar age to them, or were cared for by African servants, but white servants, governesses and teachers were preferred for girls. ${ }^{76}$ As Martens has shown, in the late 1860s and early 1870 s, there was an 'understanding that African men in Natal towns presented a danger to settler society in general and a sexual threat to white women and children in particular'. ${ }^{77}$ Legislation was passed specifically for the protection of 'women and female children'. ${ }^{78}$ In this case, however, there was more to these concerns than sexual danger: the racial identity of the white girls attending Queen Street School was particularly fragile and open to contamination from racial 'others'. Their vulnerability, because of both gender and age, made them the 
recipients of white male settler protection. The context of fears over the status of white women and children in society more broadly would have shaped the government and settler responses to their mixing with St Helenian children.

Part of what this need to protect white children, and girls in particular, from racially ambiguous others entailed was an attempt to define racial difference. There were multiple ways in which the settler community attempted to do this. First, class was used as a proxy for race, and complaints were made about the children's immorality. Hepworth had initially pointed to the elasticity of racial definitions in the colony at the time, when he argued that the children should be admitted to the school if they had 'been brought-up with the ideas and under the restraints of ordinary European civilization'. ${ }^{79}$ The arguments about class and the viciousness of the poor St Helenian children highlight the fact that race was not understood purely in terms of colour. Race also had to do with an associated set of cultural norms. In another example, when the police captain, Maxwell, went to investigate the case of the expulsion of the St Helenian children, he worried about the morality of the St Helenian mothers. He described his visit to them as follows:

The women of course were on their good behaviour while it was plain to be seen that they were of a low class and the presence of their children in the Durban School (to compare small things with great) must have had some such effect as the presence of 'ragged' Scholars would have in an ordinary board School in London, or an inroad of children from the slums of Portsmouth into a common School in a quiet country town. $^{80}$

Referring to 'ragged' scholars here positions the white, English-speaking community in opposition to this lower-class group. The references to poor whites also indicate that the St Helenian group posed a challenge to a white community which was claiming middle-class status in the colony.

Second, the correspondence surrounding the case refers to the manner in which the St Helenians spoke English or whether they behaved as English people should. Miss McClaren, the Sherrard girls' teacher, described their behaviour as 'modest + quiet, that they had not the peculiar tone + faults of pronunciation which are noticeable in St Helena children' and that the other children referred to them as 'Cape' children, rather than St Helenian children. ${ }^{81}$ Being white entailed having a good grasp of the English language and speaking the language in a particular way. ${ }^{82}$ Speaking English was not just about the use of a language-it had an associated set of values. As Ross has shown in the context of the Cape Colony in the early nineteenth century, the values of 'respectability' and 'Englishness' were often linked. ${ }^{83}$ Bickford-Smith similarly argues that in the Cape in the 1860s, 'Britishness could still be conceived of as a matter of appropriate dress, behaviour, belief and language, all attainable through education and hard work, through "progress" and "enlightenment". 84 In the case of the Sherrard children, it seemed that Crowe believed that the 
European children who attended his school had not been removed because the St Helenian children were racially other. In fact, he described Mrs Sherrard as 'a respectable Englishwoman'. He also stated that he had not removed any St Helenian children who had 'respectable English parents' ${ }^{85}$ Respectable and English in this case were synonymous. What the correspondence surrounding the case makes clear is that racial and moral objections were linked, and were difficult to distinguish from one another. In the context of an empire which claimed racial equality, making overt racial objections to the children in the school was less than acceptable to the colonial officials.

The case also highlights what was at stake for the colonial officials involved in its investigation and, indeed, sheds light on the competing ideas of Britishness in Natal. For the St Helenians, settlers and colonial officials the meanings of empire were disparate, and this, as Adele Perry reminds us, is a lesson in how historians of the British Empire should see British imperialism as 'both enormously powerful and necessarily partial and deeply compromised'. ${ }^{86}$ Alan Lester argues that 'bourgeois ideas of legitimate behaviour towards others and corresponding notions of Britishness itself moved through, and were contested within, circuits connecting Britain with each of its colonies' ${ }^{87}$ The migration of St Helenians to Natal made these networks visible.

Natal colonists drew on a settler discourse in which race and class were seen as increasingly 'irredeemable'. ${ }^{88}$ The 1870 s in Natal was a time of shoring up the status of the white elite. Although the Anglo-Zulu War started only after the case was resolved, for the settlers there was a sense of danger about being surrounded by racial 'others' that resulted in the need to protect the boundaries of their isolated community. Along with this, came the ironic need to prove themselves as 'more British than the British'. ${ }^{89}$ For the colonial officials, the settler anxieties needed to be managed in a way which did not compromise their position within a benevolent empire. St Helenians drew on a humanitarian discourse of Britishness, in which all British subjects should be seen as equal. They hoped that their status as British subjects would 'offer a resource to the dispossessed'. ${ }^{90}$ As Sukanya Banerjee points out, claims to Britishness and British citizenship often 'implicitly critiqued' British colonial practices. ${ }^{91}$ When the St Helenians used Britishness to prove their equality in Natal, they were, at the same time, critiquing the inequality in that colonial context.

This case has shown that increasing attempts were made by white Natal citizens and officials to define themselves clearly as the hegemonic elite. Any challenges to the respectability of this group in terms of class and racial otherness were met with attempts to purge this from the white community. This period saw an increasing desire on the part of settlers to define what it meant to be 'white' and to draw firm racial boundaries between the (male) respectable Self and the (female) immoral Other. The concept of 'Britishness' defied narrow definitions, and was imbued with multiple layers of meaning based on the context it drew upon. For the St Helenians arriving in Natal, it represented their claims to 
equality, while for the white Natalians it was a measure according to which this other group could be excluded from their society in general and their schools in particular.

\section{Notes}

1. T. W. Brooks to F. N. Broome, 4 Feb.1876, CSO 536 1876/270, Pietermaritzburg Archive Repository (hereafter PAR).

2. Perry, Whose World was British?, 143. As Adele Perry has argued, migration could complicate the British world and led to settler societies attempting to define these groups as either 'desirable' or 'undesirable', 'ordered principally along the axis of race'.

3. Buettner, 'Problematic Spaces, Problematic Races', 292.

4. For an overview of recent scholarship in the field, see Cleall, Ishiguro, and Manktelow, 'Imperial Relations'. See also Paisley on race and childhood in the interwar period. Paisley, 'Childhood and Race'.

5. Ibid., 283 .

6. Stoler, Carnal Knowledge, 138.

7. Bradlow, Children and Childhood at the Cape.

8. Duff, 'Saving the Child', 230, 237.

9. Errante, 'White Skin, Many Masks', 11.

10. Morrell, From Boys to Gentlemen.

11. Many of these settlers arrived under Byrne Emigration and Colonization Company settlement scheme in the 1850s. Ibid., 24.

12. Ballard, John Dunn, 35. Although, as Stoler has argued, the presence of mixed-race relationships were not always synonymous with racial equality. Stoler, 'Making Empire Respectable', 638-39.

13. Evans et al., Equal Subjects, Unequal Rights, 100.

14. Bonnett, White Identities, 12; Harris, 'Whiteness as Property', 77.

15. Killingray, 'A Good West Indian', 364-68.

16. Darian-Smith, Grimshaw and Macintyre, 'Introduction', 14. See also Schwarz, "Shivering in the Noonday Sun"'.

17. Gosse, St. Helena, 1502-1938, 373.

18. Schulenburg, 'Transient Observations'; Yon, 'Race Making/Race Mixing', 154.

19. Parker, 'Multiple Migrations', 13-14; Schulenburg, Transient observations, 200.

20. Schulenburg, 'Transient Observations', 241.

21. Melliss, St Helena, 79.

22. Schulenburg, 'Transient Observations', 243. In 1868, the governor of St Helena, Charles Elliot, complained that the St Helena population proved very difficult to classify.

23. Yon, 'Race-Making/Race-Mixing', 154.

24. Parker, 'Multiple Migrations', 12-14.

25. Saul Dubow highlights the 1870 s as a period of rapidly changing ideas about race, in response to the changing social and political landscape in South Africa. Dubow, 'How British Was the British World?', 5.

26. Yon and Schulenburg and Schulenburg have different figures here. Yon, 'RaceMaking/Race-Mixing', 154; Schulenburg and Schulenburg, St Helena, 8.

27. Brain, 'Natal's Indians, 1860-1910', 249-51.

28. Note that in the South African context public and government were, and remain, synonymous terms. Behr and Macmillan, Education in South Africa, 128. 
29. Ibid., 382 .

30. Ballard, 'Traders, Trekkers and Colonists', 129.

31. It is interesting that, in the correspondence regarding the case, the St Helenians are sometimes referred to as 'coloured' or Cape children, but never as part of the Indian group. This is probably because of the indentured labour system under which the majority of Indians were labouring, while the St Helenians were 'free born' citizens. Behr and MacMillan, Education in South Africa, 383.

32. Vietzen, History of Education for European Girls, 26.

33. Ibid., 26.

34. Minute paper, T. W. Brooks to F. N. Broome, 16 April 1875, CSO 536 1876/270, PAR.

35. R. A. Green, Letter to the Editor, Natal Mercury, 4 May 1875.

36. Minute paper, T. W. Brooks, 14 Feb. 1876, CSO 536 1876/270, PAR; Report, H. E. Bulwer to Lord Carnarvon, 26 Jan. 1876, GH 1219, PAR.

37. Minute paper, T. W. Brooks, 14 Feb. 1876, CSO 536 1876/270, APR; Report, H. E. Bulwer to Lord Carnarvon, 26 Jan. 1876, GH 1219, PAR.

38. Natal Almanac Directory and Yearly Register, 247.

39. Report, H. E. Bulwer to Lord Carnarvon, 26 Jan. 1876, GH 1219, PAR.

40. J. Crowe to T. W. Brooks, 22 March 1875, CSO 536 1876/270, PAR.

41. Ibid.; Minute paper, T. W. Brooks, 14 Feb. 1876, CSO 536 1876/270, PAR.

42. Report, H. E. Bulwer to Lord Carnarvon, 26 Jan. 1876, GH 1219, PAR.

43. After Sir Benjamin Pine had left, Sir Garnet Wolseley acted, from April to September 1875 , as the administrator of Natal. On his departure Sir Henry Bulwer assumed the role of lieutenant-governor up to April 1880. Brookes and Webb, A History of Natal, 305.

44. Sixteen St Helenian parents to G. Wolseley, 12 April 1875, CSO 536 1876/270, PAR.

45. Report, H. E. Bulwer to Lord Carnarvon, 26 Jan. 1876, GH 1219, PAR.

46. Sixteen St Helenian parents to G. Wolseley, 12 April 1875, CSO 536 1876/270, PAR.

47. H. C. Crowley, R. A. Green, T. Clarke to F. N. Broome, 21 June 1875, CSO 536 1876/ 270, PAR.

48. Ibid.

49. Ibid.

50. Duff, 'Saving the Child', 232.

51. H. C. Crowley, R. A. Green, T. Clarke to F. N. Broome, 21 June 1875, CSO 536 1876/ 270, PAR. Yon, 'Race-Making/Race-Mixing', 158. Yon recounts a story of a St Helenian woman living in Apartheid South Africa, in a 'coloured' suburb in Cape Town. When her children were discriminated against on the basis of their skin colour, Yon reports, she said: 'After all they [the offenders] should remember that I am British!'

52. R. A Green and H. C. Crowley to F. N. Broome, 28 Aug. 1875, CSO 536 1876/270, PAR.

53. Minute paper, F. N. Broome to H. E. Bulwer, 16 Dec. 1875, CSO 536 1876/270, PAR.

54. F. W. Chesson, letter to The Colonial Intelligencer, Feb. 1876.

55. Willan, 'The Anti-Slavery and Aborigines' Protection Society', 83.

56. Document titled 'Remarks', c. 1875, CSO 536 1876/270, PAR.

57. Memo, F. N. Broome, 16 Dec. 1875, CSO 536 1876/270, PAR. The term 'vicious' was also used to describe a class of parents, 'their chief vice being that of drunkenness', by Patrick Cumin in his 1861 report on ragged schools in Portsmouth and Bristol. 'Vicious' here stands for lower class. Cumin, The Popular Education of the Bristol and Plymouth Districts, 11.

58. It appears that the mother referred to here is Mrs Sherrard.

59. Minute paper, H. E. Bulwer to F. N. Broome, 5 Feb. 1876, CSO 536 1876/270, PAR. 
60. Minute paper, T. W. Brooke, 26 Jan. 1876, CSO 536 1876/270, PAR.

61. Notes, H. E. Bulwer, 25 Jan. 1876, CSO 536 1876/270, PAR.

62. Minute paper, T. W. Brooke, 26 Jan. 1876, CSO 536 1876/270, PAR.

63. Minute paper, H. E. Bulwer to F. N. Broome, 25 Jan. 1876, CSO 536 1876/270, PAR.

64. Minute paper, K. Dillon to F. N. Broome, 3 Feb.1875, CSO 536 1876/270, PAR.

65. Report, H. E. Bulwer to Lord Carnarvon, 17 Feb. 1876, GH 1219, PAR.

66. Minute paper, T. W. Brookes, 14 Feb. 1876, CSO 536 1876/270, PAR.

67. Superintendent of Education T. W. Brookes virtually managed the Natal colonial education system single-handedly with no clerical support or a budget to speak of. His work conditions, and the fact that Bulwer viewed his actions during the St Helenian school saga with suspicion, drove him over the edge and he committed suicide in April 1976. Obituary for T. W. Brooks, Natal Witness, 13 April 1876.

68. Report, H. E. Bulwer to Lord Carnarvon, 17 Feb. 1876, GH 1219, PAR. The following documents were, among others, attached as supporting evidence: sixteen St Helenian parents to G. Wolseley, 12 April 1875, CSO 536 1876/270, PAR; J. Crowe to T. W Brooks, 26 April 1875, CSO 536 1876/270, PAR; W. J. Hepworth to T. W. Brookes, 14 Jan. 1876, CSO 536 1876/270, PAR; Minute paper, H. E. Bulwer, 21 Jan. 1876, CSO 536 1876/270, PAR; Minute paper, H. E. Bulwer, 28 Jan. 1876, CSO 536 1876/ 270, PAR.

69. Report, H. E. Bulwer to Lord Carnarvon, 17 Feb. 1876, GH 1219, PAR.

70. Despatch, Natal 2575, 30 March 1876, CO 179-120, The National Archives, Kew (TNA). Our thanks to Jeff Guy for alerting us to these sources.

71. Cunningham, Children of the Poor, 191.

72. Morrell, From Boys to Gentlemen, 49.

73. Ibid., 48-49.

74. Buettner, 'Problematic Spaces, Problematic Races', 278; see also Buettner, Empire Families, ch. 2.

75. J. Crowe to T. W. Brooks, 22 March1875, CSO 536 1876/270, PAR.

76. Swaisland, Servants and Gentlewomen, 98.

77. Martens, 'Polygamy, Sexual Danger', 24.

78. Ibid., $42,33 \mathrm{n}$.

79. Minute paper, T. W. Brooks, 14 Feb. 1876, CSO 536 1876/270, PAR; Report, H. E. Bulwer to Lord Carnarvon, 26 Jan.1876, GH 1219, PAR.

80. Minute paper, T. W. Brookes, 14 Feb. 1876, CSO 536 1876/270, PAR.

81. Ibid.

82. Buettner writes that accent was seen as an important marker of class, cultural, and regional background in Britain, [while] in colonial India "chi chi" English was widely viewed as a sign of social and racial "contamination". Buettner, 'Problematic Spaces, Problematic Races', 284. It is interesting that the concerns over white children and language degeneration were occurring at the same time as the discussions over whether African children should be taught in English or in their mother-tongue languages. The civilising power of the English language was promoted by many people in colonial Natal, both missionary teachers and government officials.

83. Ross, Status and Respectability.

84. Bickford-Smith, 'African Nationalist', 90. The authors are aware of the differences between the concepts of 'Englishness' and of 'Britishness' but do not have the space to address the specificities of this distinction here.

85. J. Crowe to T. W Brooks, 26 April 1875, CSO 536 1876/270, PAR.

86. Ibid., 135.

87. Lester, 'British Settler Discourse', 26. 
88. Ibid., 31.

89. Perry, Whose World Was British?, 140

90. Schwarz, "'Shivering in the Noonday Sun", 23.

91. Banerjee, Becoming Imperial Citizens, 5.

\section{Disclosure Statement}

No potential conflict of interest was reported by the author.

\section{References}

Ballard, C. John Dunn: The White Chief of Zululand. Johannesburg: AD Donker, 1985.

Ballard, C. "Traders, Trekkers and Colonists." In Natal and Zululand from Earliest Times to 1910: A New History, edited by A. Duminy and B. Guest, 116-145. Pietermaritzburg: Natal University Press, 1989.

Banerjee, S. Becoming Imperial Citizens: Indians in the Late-Victorian Empire. Durham, NC, and London: Duke University Press, 2010.

Behr, A., and R. Macmillan. Education in South Africa. Pretoria: Van Schaik, 1971.

Bickford-Smith, V. "African Nationalist or British Loyalist? The Complicated Case of Tiyo Soga.” History Workshop Journal 71 (2011): 74-97.

Bonnett, A. White Identities: Historical and International Perspectives. Harlow: Pearson Education, 2005.

Bradlow, E. "Children and Childhood at the Cape in the 19th Century." Kleio 20, no.1 (1988): $8-27$.

Brain, J. "Natal's Indians, 1860-1910: From Co-operation, through Competition, to Conflict." In Natal and Zululand from Earliest Times to 1910: A New History, edited by A. Duminy and B. Guest, 249-274. Pietermaritzburg: Natal University Press, 1989.

Brookes, E. H., and C. de B. Webb. A History of Natal. Pietermaritzburg: University of Natal Press, 1987.

Buettner, E. Empire Families: Britons and Late Imperial India. Oxford: Oxford University Press, 2004.

Buettner, E. “Problematic Spaces, Problematic Races: Defining 'Europeans' in Late Colonial India.” Women's History Review 9 (2000): 277-298.

Cleall, E., L. Ishiguro, and E. Manktelow. "Imperial Relations: Histories of the Family in the British Empire." Journal of Colonialism and Colonial History 14, no. 1 (2013). n.p.

Cumin, P. The Popular Education of the Bristol and Plymouth Districts, with Special Reference to Ragged Schools and Pauper Children. London: Longman, Green, 1861.

Cunningham, H. The Children of the Poor: Representations of Childhood since the Seventeenth Century. Oxford: Blackwell, 1991.

Darian-Smith, K., P. Grimshaw, and S. Macintyre. "Introduction.” In Britishness Abroad: Transnational Movements and Imperial Cultures, edited by Kate Darian-Smith, Patricia Grimshaw, and Stuart Macintyre, 1-15. Melbourne: Melbourne University Press, 2007.

Dubow, S. "How British Was the British World? The Case of South Africa." The Journal of Imperial and Commonwealth History 37 (2009): 1-27.

Duff, S. "Saving the Child to Save the Nation: Poverty, Whiteness and Childhood in the Cape Colony, c.1870-1895." Journal of Southern African Studies 37 (2011): 229-245.

Errante, A. "White Skin, Many Masks: Colonial Schooling, Race and National Consciousness among white Settler Children in Mozambique, 1934-1974." The International Journal of African Historical Studies 36, no. 1 (2003): 7-33. 
Evans, J., P. Grimshaw, D. Philips, and S. Swain. Equal Subjects, Unequal Rights: Indigenous People in British Settler Colonies, 1830 - 1910. Manchester: Manchester University Press, 2003.

Gosse, P. St Helena 1502-1938. London: Anthony Nelson, 1990.

Harris, C. "Whiteness as Property." In Identities: Race, Class, Gender and Nationality, edited by L. Alcoff and E. Mendieta, 75-89. Malden, MA: Blackwell, 2003.

Killingray, D. “'A Good West Indian, a Good African, and, in Short, a Good Britisher': Black and British in a Colour-Conscious Empire, 1760-1950." The Journal of Imperial and Commonwealth History 36 (2008): 363-381.

Lester, A. "British Settler Discourse and the Circuits of Empire." History Workshop Journal 54 (2002): 24-48.

Martens, J. "Polygamy, Sexual Danger, and the Creation of Vagrancy Legislation in Colonial Natal." The Journal of Imperial and Commonwealth History 31, no. 3 (2003): 24-45.

Melliss, J. C., with drawings by Mrs J. C. Melliss. St Helena: A Physical, Historical and Topographical Description of the Island, Including Its Geology, Fauna, Flora and Meteorology. London: L Reeve, 1875.

Morrell, R. From Boys to Gentlemen: Settler Masculinities in Colonial Natal, 1880-1920. Pretoria: Unisa Press, 2001.

Natal Almanac Directory and Yearly Register. Pietermaritzburg: P. Davis, 1874.

Paisley, F. "Childhood and Race: Growing up in the Empire." In Gender and Empire, edited by Phillipa Levine, 240-259. Oxford: Oxford University Press, 2004.

Parker, C. "Multiple Migrations and the Repertoires of a St Helenian Identity." PhD thesis, University of Warwick, 2012.

Perry, A. "Whose World Was British? Rethinking the 'British World' from the Edge of Empire." In Britishness Abroad: Transnational Movements and Imperial Cultures, edited by K. Darian-Smith, P. Grimshaw and S. Macintyre, 133-152. Melbourne: Melbourne University Press, 2007.

Ross, R. Status and Respectability in the Cape Colony, 1750-1870. Cambridge: Cambridge University Press, 1999.

Schulenberg, A. H. "Transient Observations: The Textualisation of St Helena through Five Hundred Years of Colonial discourse." PhD thesis, University of St Andrews, 1999.

Schulenburg, H., and A. Schulenburg. St Helena: South Atlantic Ocean. Allersberg: Jacob-Gilardi-Verlag, 1997.

Schwarz, B. "Shivering in the Noonday Sun': The British World and the Dynamics of 'Nativisation'." In Britishness Abroad: Transnational Movements and Imperial Cultures, edited by Kate Darian-Smith, Patricia Grimshaw, and Stuart Macintyre, 19-44. Melbourne: Melbourne University Press, 2007.

Stoler, A. L. Carnal Knowledge and Imperial Power: Race and the Intimate in Colonial Rule. London: University of California Press, 2002.

Stoler, A. L. "Making Empire Respectable: The Politics of Race and Sexual Morality in 20thcentury Colonial Cultures.” American Ethnologist 16, no. 4 (1989): 634-660.

Swaisland, C. Servants and Gentlewomen to the Golden Land: The Emigration of Single Women from Britain to Southern Africa, 1820-1939. Oxford: Berg, 1993.

Vietzen, S. A History of Education for European Girls in Natal 1837-1902. Pietermaritzburg: University of Natal Press, 1980.

Willan, B. "The Anti-Slavery and Aborigines' Protection Society and the South African Natives' Land Act of 1913." The Journal of African History 20 (1979): 83-102.

Yon, D. A. "Race-Making/Race-Mixing: St. Helena and the South Atlantic World." Social Dynamics: A Journal of African Studies 33, no. 2 (2008): 144-163. 